\title{
The Mechanism of Intracellular Acidification Induced by Glucose in Saccharomyces cerevisiae
}

\author{
By SOFía RAMOS,* MILAgRos BALbín, MARTA RAPOSO, \\ EULALIA VALLE AND LUIS A. PARDO \\ Departamento de Biologia Funcional, Universidad de Oviedo, Oviedo, Spain
}

(Received 9 February 1989; accepted 21 April 1989)

\begin{abstract}
Addition of glucose or fructose to cells of Saccharomyces cerevisiae adapted to grow in the absence of glucose induced an acidification of the intracellular medium. This acidification appeared to be due to the phosphorylation of the sugar since: (i) glucose analogues which are not efficiently phosphorylated did not induce internal acidification; (ii) glucose addition did not cause internal acidification in a mutant deficient in all the three sugar-phosphorylating enzymes; (iii) fructose did not affect the intracellular $\mathrm{pH}$ in a double mutant having only glucokinase activity; (iv) glucose was as effective as fructose in inducing the internal $\mathrm{pH}$ drop in a mutant deficient in phosphoglucose isomerase activity; and (v) in strains deficient in two of the three sugar-phosphorylating activities, there was a good correlation between the specific glucose- or fructose-phosphorylating activity of cell extracts and the sugar-induced internal acidification. In addition, in whole cells any of the three yeast sugar kinases were capable of mediating the internal acidification described. Glucose-induced internal acidification was observed even when yeast cells were suspended in growth medium and in cells suspended in buffer containing $\mathrm{K}^{+}$, which supports the possible signalling function of the glucose-induced internal acidification. Evaluation of internal $\mathrm{pH}$ by following fluorescence changes of fluorescein-loaded cells indicated that the change in intracellular $\mathrm{pH}$ occurred immediately after addition of sugar. The apparent $K_{\mathrm{m}}$ for glucose in this process was $2 \mathrm{mM}$. Changes in both the internal and external $\mathrm{pH}$ were determined and it was found that the internal acidification induced by glucose was followed by a partial alkalinization coincident with the initiation of $\mathrm{H}^{+}$efflux. This reversal of acidification could be due to the activity of the $\mathrm{H}^{+}$-ATPase, since it was inhibited by diethylstilboestrol. Coincidence between internal alkalinization and the $\mathrm{H}^{+}$efflux was also observed after addition of ethanol.
\end{abstract}

\section{INTRODUCTION}

It has become evident that changes in internal $\mathrm{pH}\left(\mathrm{pH}_{\mathrm{in}}\right)$ mediate many important cellular processes (Busa \& Nuccitelli, 1984). Intracellular pH is important for the activity of a number of enzymes with $\mathrm{pH}$ optima within the physiological range as well as for the efficiency of contractile elements and the conductivity of ion channels (Madshus, 1988). Moreover, pH oscillations seem to be important in controlling the cell cycle and proliferative capacity of cells. Low intracellular $\mathrm{pH}$ is common to both prokaryotic and eukaryotic resting cells. This is believed to be one of the reasons for the low metabolic activities of cells in this state (Madshus, 1988). Grinstein et al. (1987) reported that in various eukaryotic cells, upon cell activation, the intracellular $\mathrm{pH}$ generally rises; however, this alkalinization is preceded by a transient internal acidification. The causes of this acidification are not fully understood and differ in various cell types. NADPH oxidation is thought to be important in the acidification observed in cytoplasts activated with phorbol esters (Henderson et al., 1988). In platelets, the internal increase in $\mathrm{H}^{+}$

Abbreviation: DES, diethylstilboestrol. 
concentration caused by platelet-derived growth factor and bombesin is thought to be the result of a rise in intracellular free $\mathrm{Ca}^{2+}$ which is exchanged for $\mathrm{H}^{+}$(Ives \& Daniel, 1987). The further alkalinization is mainly due to the activation of the $\mathrm{Na}^{+} / \mathrm{H}^{+}$antiport in all mammalian cells. This antiport can be rapidly activated in an ATP-independent fashion by internal acidification or by an ATP-dependent process mediated by a $\mathrm{Ca}^{2+}$-dependent protein kinase or by tyrosine kinases (Grinstein et al., 1987).

In yeasts, it has long been known that the addition of sugars causes the appearance of acids in the external medium. This external acidification, which is due to the activity of a $\mathrm{H}^{+}$-ATPase (Goffeau \& Slayman, 1981; Serrano, 1984) and to the excretion of acids (Wurst et al., 1980), has been correlated with the internal alkalinization observed on addition of a carbon source (Serrano, 1984). However, an exchange of $\mathrm{H}^{+}$for $\mathrm{K}^{+}$also seems to be involved. This system has been characterized in Neurospora crassa (Blaat \& Slayman, 1987) and observed in Saccharomyces cerevisiae (Valle et al., 1987). This alkalinization is preceded by an acidification (den Hollander et al., 1981; Nicolay et al., 1982; Caspani et al., 1985; Valle et al., 1986; Thevelein et al., 1987b) which, in the presence of external $\mathrm{K}^{+}$, is transient but in its absence lasts for at least $10 \mathrm{~min}$ (Valle et al., 1987). The cause of the decrease of $\mathrm{pH}_{\text {in }}$ induced by glucose is not fully understood, but may be due to the accumulation of either $\mathrm{CO}_{2}$ (den Hollander et al., 1981), glucose 6-phosphate (Valle et al., 1987; Eraso et al., 1987) or other organic acids, since one of the known effects of glucose is the production and secretion of these substances (Duro \& Serrano, 1981; Wurst et al., 1981).

In $S$. cerevisiae addition of glucose also induces an increase in cyclic AMP (cAMP) levels (van der Plaat \& van Soligen, 1974; Mazón et al., 1982). Increased cAMP levels are also observed, in the absence of glucose, when an internal acidification is caused by other means (Caspani et al., 1985; Thevelein et al., 1987a). These results, and the demonstration that adenylate cyclase is twice as active at $\mathrm{pH} 6.5$ as at $\mathrm{pH} 7.0$, lead Purwin et al. (1986) to postulate that glucosedependent increases of cAMP levels are mediated by the fall in $\mathrm{pH}_{\mathrm{in}}$. This hypothesis is not generally accepted, since Eraso $e t$ al. (1987) found that a rise in cAMP precedes the glucoseinduced internal acidification. In addition, Thevelein et al. (1987b) have shown an increase in cAMP under conditions where acidification was prevented. They therefore considered that internal acidification induced by glucose does not mediate the increase in cAMP in S. cerevisiae.

In this paper the time-course of changes in internal and external $\mathrm{pH}$ were determined using a fluorescent probe which allowed determination of fast changes in $\mathrm{pH}_{\mathrm{in}}$.

\section{METHODS}

Yeast strains and culture conditions. The following strains of Saccharomyces cerevisiae were used (all obtained from the Yeast Genetic Stock Center, Berkeley, Calif., USA): ATCC 52300 (MAT $\alpha$ his); D 308 (MAT $\alpha$ hxkl $h x k 2$ adel trpl his2 met4); P1T8C (MATa $h x k 2$ glk1 adel); P2T22D (MAT $\alpha$ hxkl glkl adel) and D 308.3 (MAT $\alpha$ hxkl hxk2 glkl adel trpl his2 met4). In addition, strain AA28 (MATa pgild25 : : LEU2 leu2-3-112 ura3$52 \operatorname{trp} 1$ ) was kindly provided by Dr A. Aguilera (Aguilera, 1986). The yeasts were cultured at $28^{\circ} \mathrm{C}$ with shaking. The media used were as follows: YNB $[1.4 \%, w / v$, Yeast Nitrogen Base (Difco) and $2 \%, w / v$, glucose or $2 \%, v / v$, ethanol]; YPD $(1 \%, w / v$, yeast extract, $2 \%, w / v$, peptone, $2 \%$ glucose); YPFruct. (1 yeast extract, $2 \%$ peptone, $2 \%, \mathrm{w} / \mathrm{v}$, fructose and $0.1 \%$ glucose). Cells were harvested by centrifugation, washed twice with distilled water and resuspended in the appropriate buffer.

Determination of $\mathrm{pH}_{\text {in }}$. Two different methods were used: measuring the accumulation of the weak acid benzoic acid and/or following the changes in fluorescence of fluorescein. Unless indicated the determination of internal pH with $\left[{ }^{14} \mathrm{C}\right]$ benzoic acid $\left[29.4 \mathrm{Ci} \mathrm{mol}^{-1}\left(1.088 \mathrm{TBq} \mathrm{mol}^{-1} ; 1.4 \mu \mathrm{M}\right)\right]$ was done using the acid concentration gradient reached at steady state as previously described (Valle et al., 1986), in cells suspended in $50 \mathrm{~mm}$ 6-aminohexanoate/ $\mathrm{HCl}$ buffer, $\mathrm{pH} \mathrm{4.5}$, at a density of $1.6 \times 10^{8}$ cells $\mathrm{ml}^{-1}$. The determination of $\mathrm{pH}_{\text {in }}$ with fluorescein was done according to the method described by Slavik (1982) with some modifications. The cells were washed twice with distilled water and incubated at a concentration of $1.6 \times 10^{8}$ cells $\mathrm{ml}^{-1}$ at $30^{\circ} \mathrm{C}$ for 20 min in universal buffer (50 mM-6-aminohexanoate, $50 \mathrm{mM}$-MES, $50 \mathrm{~mm}$-HEPES, adjusted to pH 6.9 with $\mathrm{HCl}$ ) containing $100 \mu \mathrm{M}$-fluorescein diacetate (Sigma). Cells were then washed twice with ice-cold $50 \mathrm{~mm}$ 6-aminohexanoate/ $\mathrm{HCl}$ buffer, $\mathrm{pH} 4 \cdot 5$, or $50 \mathrm{mM}-\mathrm{MES} / \mathrm{NaOH}$ buffer, $\mathrm{pH} 6 \cdot 0$, resuspended in the same buffer at a cell density of $1.6 \times 10^{8}$ cells $\mathrm{ml}^{-1}$ and kept on ice until use. For a standard assay, $0.1 \mathrm{ml}$ of this suspension was added to $3 \mathrm{ml} 50 \mathrm{~mm}-6$-aminohexanoate buffer, $\mathrm{pH} 4.5$, or $50 \mathrm{mM}-\mathrm{MES} / \mathrm{NaOH}$ buffer, $\mathrm{pH} 6.0$, and the fluorescence emitted at $520 \mathrm{~nm}$ was recorded at $20^{\circ} \mathrm{C}$ after excitation at 490 and $435 \mathrm{~nm}$. Fluorescence 
measurements were made in a Perkin-Elmer MPF-44A fluorescence spectrophotometer. A 3 ml cuvette was used in which continuous and efficient stirring was ensured by using a small plastic stick coupled to an electric mixer attached to the cover of the sample compartment. The fluorescein fluorescence emitted at $\lambda_{\text {ex. }} 490 \mathrm{~nm}$ was continuously monitored since it is affected by $\mathrm{pH}$ changes whereas the fluorescence emitted at $\lambda_{\text {ex. }} 435 \mathrm{~nm}$ was recorded for only a few seconds, several times during each experiment. The values of intracellular pH were obtained from the fluorescence ratio $490 \mathrm{~nm} / 435 \mathrm{~nm}$ using a calibration curve prepared as described by Slavik (1982).

Potentiometric measurements of $\mathrm{pH}_{\text {out }}$. The external $\mathrm{H}^{+}$concentration was continuously monitored in a waterjacketted vessel at $20^{\circ} \mathrm{C}$ containing $10 \mathrm{ml}$ of cell suspension $\left(0.5 \times 10^{8}\right.$ cells ml $\left.{ }^{-1}\right)$ in $5 \mathrm{~mm}-6$-aminohexanoate $/ \mathrm{HCl}$ buffer, pH 4.5. Ingold glass $\mathrm{H}^{+}$-sensitive electrodes were used. Electrodes were coupled to a pH meter PHM 64 (Radiometer) and the results were recorded on a two-channel LKB recorder.

Hexose phosphorylating-activity. This was determined in yeast homogenates as described by Fernández et al. (1985).

\section{RESULTS}

\section{Effect of sugars on $p H_{\text {in }}$ of $S$. cerevisiae}

The $\mathrm{pH}_{\text {in }}$ of cells prior to the addition of the sugars was 6.8 . As described previously (den Hollander et al., 1981; Nicolay et al., 1982; Caspani et al., 1985; Valle et al., 1986), the addition of $20 \mathrm{mM}$-glucose or other sugars which are degraded through glycolysis lowered $\mathrm{pH}_{\text {in }}$ to about 6.4 (Table 1). Among the non-metabolizable sugars and sugar derivatives tested, those which are not efficiently phosphorylated (Sols et al., 1958; Gancedo \& Gancedo, 1985; Siverio et al., 1986) such as xylose $(150 \mathrm{mM}), 3-O$-methyl D-glucoside $(20 \mathrm{mM})$ or 6-deoxy-D-glucose (100 mM) had little effect on $\mathrm{pH}_{\mathrm{in}}$. However, 2-deoxy-D-glucose $(20 \mathrm{~mm})$, which is phosphorylated but not subsequently metabolized, caused a drop of $\mathrm{pH}_{\text {in }}$ similar to that produced by glucose. 6-Deoxy-Dglucose $(100 \mathrm{mM})$ was used to ensure access of the analogue to the inside of the cells since lowaffinity transport systems have been demonstrated whenever glucose or its analogues are transported with no further phosphorylation (Bisson \& Fraenkel, 1983; Ongjoco et al., 1987). These results indicate that phosphorylation is required for a sugar to cause intracellular acidification. This hypothesis is further supported by the fact that glucose (100 mM) does not affect the internal pH in strain 308.3 ( $h x k l h x k 2 \mathrm{glk}$ ), which lacks the three glucose phosphorylating enzymes (100 mM-glucose was used in this case for the same reasons as explained for 6-deoxy-D-glucose). On the other hand, glucose (20 mM) as well as fructose (20 mM)

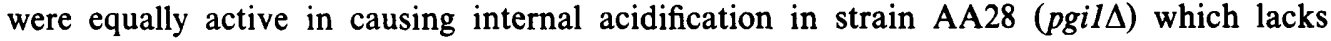
phosphoglucose isomerase activity. Addition of sorbitol ( $150 \mathrm{mM})$, which is not metabolized by yeasts and had no effect on $\mathrm{pH}_{\mathrm{in}}$, was assayed to test for any osmotic effect.

\section{Role of glucose-phosphorylating enzymes on glucose-induced internal acidification}

Three phosphorylating enzymes have been described for $S$. cerevisiae: hexokinase PI is a constitutive enzyme (Fernández et al., 1985) with a ratio of fructose to glucose phosphorylating activities of 2.5; glucokinase synthesis is repressed by glucose and is specific for glucose; hexokinase PII is an enzyme whose synthesis is induced by the presence of glucose (Fernández et $a l ., 1985)$ and which may be involved in catabolite repression (Entian \& Mecke, 1981). This latter enzyme catalyses the phosphorylation of fructose and glucose at the same rate (Barnard 1975; Gancedo et al., 1977). To test whether the effect of glucose on $\mathrm{pH}_{\text {in }}$ was dependent on the activity of any of these enzymes in particular, the intracellular $\mathrm{pH}$ of three double mutants (D 308, PIT8C and P2T22D), each having only one of the three phosphorylating enzymes, was determined before and after the addition of $20 \mathrm{~mm}$ glucose or fructose. Exponential-phase cells grown on minimal medium with ethanol as carbon source were suspended in 6-aminohexanoate/ $\mathrm{HCl}$ buffer $(50 \mathrm{~mm}), \mathrm{pH} 4.5$, and $\mathrm{pH}_{\mathrm{in}}$ was evaluated from the accumulation of $\left[{ }^{14} \mathrm{C}\right]$ benzoic acid. Strain D $308(h x k l h x k 2)$, which has only glucokinase activity, had a $\mathrm{pH}_{\text {in }}$ of 6.2 in the absence of glucose. In the presence of $20 \mathrm{~mm}$-glucose the $\mathrm{pH}_{\text {in }}$ was 4.8 ; addition of fructose (20 mM) had no significant effect. Strain P1T8C ( $h x k 2 \mathrm{glk})$, which has only hexokinase PI, had a basal $\mathrm{pH}_{\text {in }}$ of 6.6 which fell to 6.4 in the presence of glucose and 5.7 in the presence of fructose. Strain P2T22D ( $h x k 1$ glk), which has only hexokinase PII, had a basal $\mathrm{pH}_{\text {in }}$ of 6.4 , which fell to about 5.7 in the presence of glucose or fructose. 
Table 1. Effect of different sugars and glucose analogues on $p H_{\text {in }}$ of $S$. cerevisiae

$\mathrm{pH}_{\text {in }}$ was measured in cells suspended in 50 mM-6-aminohexanoate/ $\mathrm{HCl}$ buffer, $\mathrm{pH} \mathrm{4.5}$, from the distribution at steady state of $\left[{ }^{14} \mathrm{C}\right]$ benzoic acid $(1.4 \mu \mathrm{M})$. Sugars or derivatives were added at time zero. Strain ATCC 52300 was grown in minimal medium with glucose as carbon source and harvested $10 \mathrm{~h}$ after the glucose was exhausted in the medium. Strain D 308.3 was grown in minimal medium with ethanol as carbon source and harvested during the exponential phase of growth. Strain AA28 was grown in YPFruct. medium containing $0.1 \%$ glucose and harvested during the stationary phase. Values are means of different experiments (number given in parentheses).

Strain

ATCC 52300

D $308.3(h x k 1 h x k 2$ glk)

AA28 (pgilı)
Addition

\section{None}

Glucose (20 mM)

Fructose $(20 \mathrm{~mm})$

2-Deoxy-D-glucose $(20 \mathrm{~mm})$

6-Deoxy-D-glucose (100 mM)

3-O-Methylglucoside ( $20 \mathrm{~mm}$ )

Xylose (150 mM)

Sorbitol (150 mM)

None

Glucose (100 mM)

None

Glucose (20 mM)

Fructose (20 mM)

$$
\mathrm{pH}_{\text {in }}
$$

$6.85(28)$

$6.41(12)$

$6.36(4)$

$6.45(6)$

$6 \cdot 80(5)$

$7.00(4)$

$7.05(2)$

$6.89(3)$

$6.52(3)$

$5.90(3)$

$5.85(3)$

Table 2. Relationship between glucose- and fructose-phosphorylating activities and the change in $\mathrm{pH}_{\text {in }}$ induced by addition of glucose or fructose to mutants having only one of the three sugar kinases

Strains were grown and harvested as indicated in the legend to Fig. 1. The sugar-phosphorylating specific activities were determined in cell-free extracts; Values are means of two different experiments. The values for decrease of $\mathrm{pH}_{\mathrm{in}}(\Delta \mathrm{pH})$ induced by addition of glucose or fructose are taken from data described in the text and are means of five independent determinations.

\begin{tabular}{|c|c|c|c|c|}
\hline \multirow[b]{2}{*}{ Strain (enzyme present) } & \multicolumn{2}{|c|}{$\begin{array}{c}\text { Specific activity } \\
{\left[\mu \mathrm{mol} \min ^{-1}(\mathrm{mg} \text { protein })^{-1}\right]}\end{array}$} & \multicolumn{2}{|c|}{$\Delta \mathrm{pH}$} \\
\hline & Glucose & Fructose & Glucose & Fructose \\
\hline $\begin{array}{l}\text { D } 308 \text { (glucokinase) } \\
\text { P1T8C (hexokinase PI) } \\
\text { P2T22D (hexokinase PII) }\end{array}$ & $\begin{array}{l}917 \\
207 \\
561\end{array}$ & $\begin{array}{l}168 \\
610 \\
561\end{array}$ & $\begin{array}{l}-1.44 \\
-0.24 \\
-0.67\end{array}$ & $\begin{array}{l}-0.06^{*} \\
-0.90 \\
-0.53\end{array}$ \\
\hline
\end{tabular}

* Not statistically significant.

The specific activity of glucose- and fructose-phosphorylating enzymes of these strains was measured in extracts of cells collected under the same conditions as above, in order to correlate these values with the effect of the sugars on the $\mathrm{pH}_{\mathrm{in}}$ of whole cells. A good correlation was observed between these two parameters (Table 2). Thus strain D 308, where glucose induced the largest acidification, also had the highest specific glucose-phosphorylating activity. Furthermore fructose, which showed no significant effect on $\mathrm{pH}_{\text {in }}$ in this strain, had the lowest specific fructose-phosphorylating activity. The correlation between hexose-phosphorylating specific activities and intracellular acidification also held for strains P1T8C and P2T22D. These results are further evidence that the acidification induced by the addition of glucose is due to the phosphorylation of the sugar and that any of the three sugar kinases are able to mediate this effect.

\section{Effect of glucose addition to cells suspended in growth medium}

The above data show that glucose causes a drop of $\mathrm{pH}_{\text {in }}$ when cells are resuspended in $50 \mathrm{~mm}$ 6-aminohexanoate/ $\mathrm{HCl}$ buffer, $\mathrm{pH} 4 \cdot 5$. However, it has been shown that in the presence of 


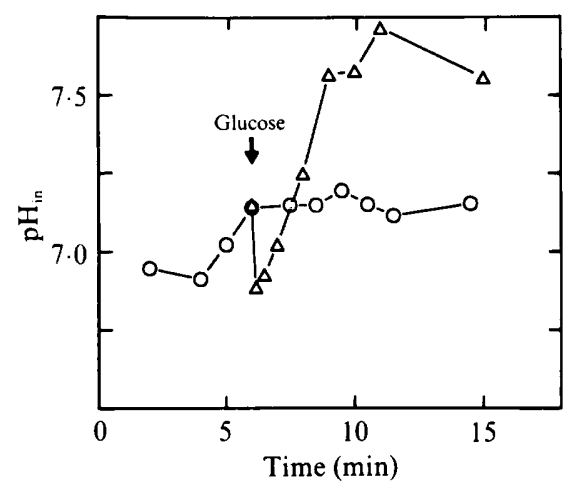

Fig. 1. Effect of glucose addition on $\mathrm{pH}_{\mathrm{in}}$ of cells suspended in growth medium. $S$. cerevisiae ATCC 52300 was grown to stationary phase in minimal medium with glucose as carbon source at $28^{\circ} \mathrm{C}$ with shaking. A culture sample $(3 \mathrm{ml})$ containing $5 \times 10^{7}$ cells ml-1 was transferred to a $25 \mathrm{ml}$ flask and further incubated for $2 \mathrm{~h}$ with shaking. Then $\left[{ }^{14} \mathrm{C}\right]$ benzoic acid $(4.25 \mu \mathrm{M})$ was added and samples subsequently analysed as described in Methods. The acid distribution and $\mathrm{pH}_{\mathrm{in}}$ were determined taking into account the external pH (3.1) of the medium. $\bigcirc$, Control; $\triangle, 10 \mathrm{~mm}$-glucose (the arrow indicates the time of addition). Similar results were obtained in three different determinations.

external $\mathrm{K}^{+}$the acidification induced by glucose is transient and is followed by an alkalinization (Valle et al., 1987). If the acidification caused by glucose has any signalling function it should also occur in cells suspended in culture medium. This is precisely the case shown in Fig. 1, where $\mathrm{pH}_{\text {in }}$ was evaluated from $\left[{ }^{14} \mathrm{C}\right]$ benzoic acid accumulation from the same medium in which the cells were growing. The $\mathrm{pH}_{\text {in }}$ of cells in these conditions was $7 \cdot 1$. Addition of glucose caused a sudden drop which varied between $0 \cdot 1-0 \cdot 3 \mathrm{pH}$ units in different experiments, followed by a rise of $\mathrm{pH}_{\mathrm{in}}$ to a value of $7 \cdot 7,6 \mathrm{~min}$ after addition of glucose.

\section{Time-course of internal and external acidification after addition of a carbon source}

The change in $\mathrm{pH}_{\text {in }}$ represents a balance between $\mathrm{H}^{+}$efflux and $\mathrm{H}^{+}$formation due to the phosphorylation of glucose. The time-course of these two processes was studied when glucose was added to cells in the stationary phase of growth. The external $\mathrm{pH}\left(\mathrm{pH}_{\text {out }}\right)$ was determined with $\mathrm{pH}$ electrodes and the changes in $\mathrm{pH}_{\text {in }}$ were evaluated in fluorescein-loaded cells. This $\mathrm{pH}-$ dependent fluorescent dye was used because it allows better time resolution of $\mathrm{pH}$ changes. Fig. $2 a$ shows that before addition of glucose, both $\mathrm{pH}_{\text {out }}$ (trace $\mathrm{A}$ ) and $\mathrm{pH}_{\text {in }}(\operatorname{traces} \mathrm{B}$ and $\mathrm{C}$ ) were steady. Addition of $10 \mathrm{~mm}$-glucose caused an immediate decrease in the fluorescein fluorescence ratio $490 \mathrm{~nm} / 435 \mathrm{~nm}$. This represents an intracellular acidification which had a maximum of $0.4 \mathrm{pH}$ units and was reached $30 \mathrm{~s}$ after the addition of sugar. A partial internal alkalinization followed which, in the absence of external $\mathrm{K}^{+}$, remained below the original value; in the presence of $10 \mathrm{mM}$ external $\mathrm{K}^{+}, \mathrm{pH}_{\mathrm{in}}$ returned to values higher than the original (see below). $\mathrm{pH}_{\text {out }}$ was also lowered after addition of glucose, but only after a $30 \mathrm{~s}$ delay. Thus delay in $\mathrm{H}^{+}$ efflux was coincident with the start of intracellular alkalinization, suggesting that the change in $\mathrm{pH}_{\text {in }}$ may represent the activity of the $\mathrm{H}^{+}$-ATPase. This is supported by the effect of the $\mathrm{H}^{+}-$ ATPase inhibitor diethylstilboestrol (DES). In its presence the change in cell fluorescence which followed the acidification induced by glucose was not observed (Fig. $2 a$, trace C). Contrary to what has been described by Serrano (1980) in starved cells, we were unable to observe any effect of DES on external acidification when freshly harvested cells were treated with this inhibitor. The lack of effect of DES on $\mathrm{H}^{+}$efflux might indicate that the contribution of the membranebound $\mathrm{H}^{+}-\mathrm{ATPase}$ to the external acidification under these conditions is small and that the change in $\mathrm{pH}_{\text {in }}$ determined with fluorescein could be a more reliable method to assay in vivo the activity of the $\mathrm{H}^{+}$-ATPase than the acidification of the external medium, in which acid efflux may also be involved (Duro \& Serrano, 1981; Wurst et al., 1980).

Simultaneous $\mathrm{H}^{+}$efflux and internal alkalinization were also observed (Fig. $2 b$ ) when the effect of ethanol and $\mathrm{H}_{2} \mathrm{O}_{2}$ on the fluorescence of fluorescein-loaded cells (trace $\mathrm{B}$ ) and $\mathrm{H}^{+}$efflux 


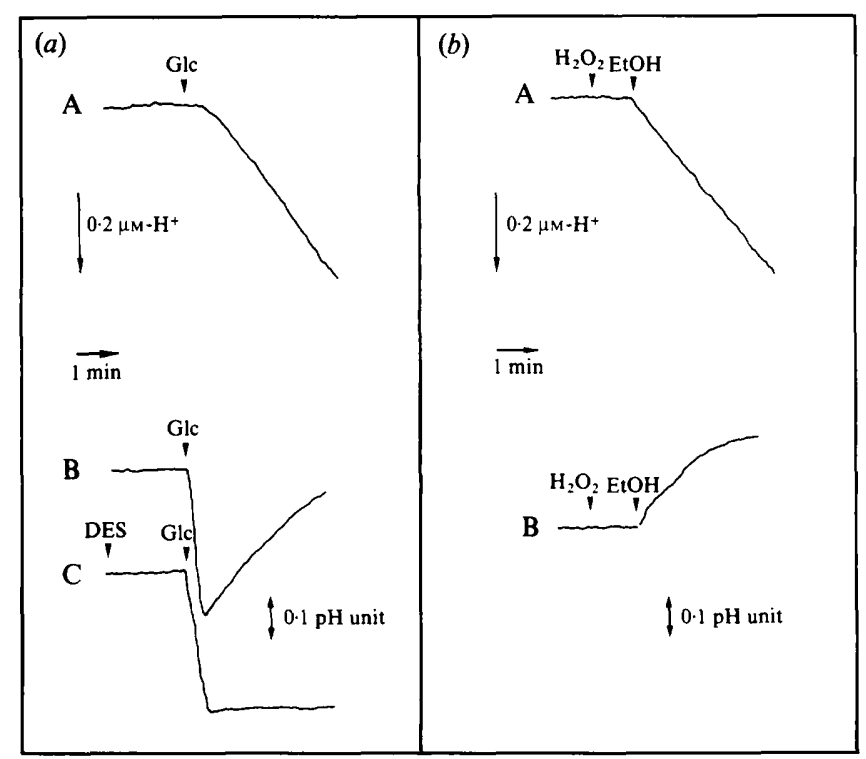

Fig. 2. Time-course of external and internal acidification after the addition of glucose $(a)$ and ethanol (b) to $S$. cerevisiae. (a) Cells of $S$. cerevisiae ATCC 52300, grown and harvested as in Table 1 , were suspended $\left(0.5 \times 10^{8}\right.$ cells $\left.\mathrm{ml}^{-1}\right)$ in $5 \mathrm{mM}-6$-aminohexanoate $/ \mathrm{HCl}$ buffer, $\mathrm{pH} 4.5$. A sample $(2.5 \mathrm{ml})$ of this suspension was transferred to a cuvette with stirring and the external $\mathrm{pH}$ monitored with a $\mathrm{pH}$ electrode (trace A). The arrow indicates addition of $10 \mathrm{~mm}$-glucose (Glc). For measurement of $\mathrm{pH}_{\text {in }}$ (traces B and C) the cells were loaded with fluorescein and suspended $\left(1.6 \times 10^{8} \mathrm{cells} \mathrm{ml}^{-1}\right)$ in $50 \mathrm{mM}-6$ aminohexanoate/ $\mathrm{HCl}$ buffer, $\mathrm{pH} 4.5$. A sample $(100 \mu \mathrm{l})$ of this suspension was added to $3 \mathrm{ml}$ of the same buffer in a spectrofluorimeter cuvette. Traces $B$ and $\mathrm{C}$ show the intracellular $\mathrm{pH}$ changes calculated from the ratio of fluorescence emitted at $520 \mathrm{~nm}$ when the excitation wavelength was $490 \mathrm{~nm}$ or $435 \mathrm{~nm}$ (see Methods). When indicated, $10 \mathrm{~mm}$-glucose or $16 \mu \mathrm{g} \mathrm{DES} \mathrm{ml^{-1 }}$ was added. (b) (trace A). The external $\mathrm{pH}$ was determined as described above (in trace $\mathrm{A}$ ) but with cells grown in minimal medium with $2 \%(v / v)$ ethanol as carbon source and harvested in the late exponential phase of growth. When indicated, ethanol (EtOH) $(0.1 \%)$ and $\mathrm{H}_{2} \mathrm{O}_{2}(0.005 \%)$ were added. For trace $\mathrm{B}, \mathrm{pH}_{\text {in }}$ was determined by the fluorescence method but in cells grown on ethanol as carbon source.

(trace A) were determined. $\mathrm{H}^{+}$efflux was observed without any delay after the addition of the carbon source, which agrees with the fact that the alkalinization of the internal medium was not preceded by an acidification (trace B). The addition of glucose to these ethanol-grown cells caused effects similar to those described for glucose-grown cells in Fig. 2(a) (data not shown).

\section{Effect of external $\mathrm{K}^{+}$on glucose-induced internal acidification}

External $\mathrm{K}^{+}$, in the presence of glucose, caused an intracellular alkalinization (Valle et al., 1987). However, Eraso et al. (1987) found that at an external $\mathrm{pH}$ of 6.0, and in the presence of $\mathrm{K}^{+}$, addition of glucose did not produce an appreciable internal acidification as measured with weak acids. Since the change in $\mathrm{pH}_{\text {in }}$ induced by glucose in cells suspended in culture medium (Fig. 1) was smaller and more variable than that determined in cells suspended in buffer (described above) it was important to determine the extent of the glucose-induced internal acidification in the presence of $\mathrm{K}^{+}$by the fluorescein method. Addition of $10 \mathrm{~mm}$-glucose caused a transient decrease in fluorescein fluorescence, corresponding to a fall of $0.5-0.6 \mathrm{pH}$ units, at $\mathrm{pH}_{\text {out }}$ values of 4.5 or 6.0 (Fig. 3). This decrease is similar to the values observed in the absence of external $\mathrm{K}^{+}$(Fig. $2 a$, trace B). Acidification was followed by a greater intracellular alkalinization than observed in the absence of $\mathrm{K}^{+}, \mathrm{pH}_{\mathrm{in}}$ reaching values higher than the original.

\section{Kinetics of glucose-induced internal acidification}

The rate of decrease of fluorescence after addition of glucose depended on the concentration of added glucose (Fig. 4). The apparent $K_{\mathrm{m}}$ for glucose-induced acidification was $2 \mathrm{~mm}$, a value 


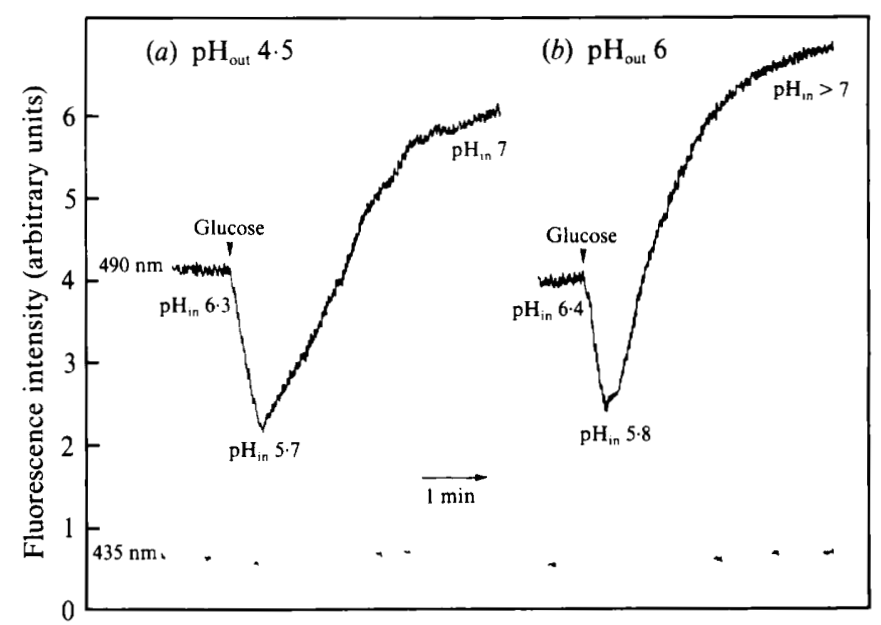

Fig. 3. Effect of external $\mathrm{K}^{+}$on glucose-induced internal acidification in $S$. cerevisiae. Fluoresceinloaded cells were suspended in $50 \mathrm{~mm}$-6-aminohexanoate/ $\mathrm{HCl}$ buffer, $\mathrm{pH} 4.5$, plus $10 \mathrm{mM}-\mathrm{KCl}(a)$ or in $50 \mathrm{~mm}-\mathrm{MES} / \mathrm{NaOH}$ buffer, $\mathrm{pH} 6.5$, plus $10 \mathrm{~mm}-\mathrm{KCl}(b)$. The fluorescence emitted at $520 \mathrm{~nm}$ when the excitation wavelength was $490 \mathrm{~nm}$ or $435 \mathrm{~nm}$ is shown. Values of $\mathrm{pH}_{\text {in }}$ determined from the fluorescence ratio $490 \mathrm{~nm} / 435 \mathrm{~nm}$ are given.

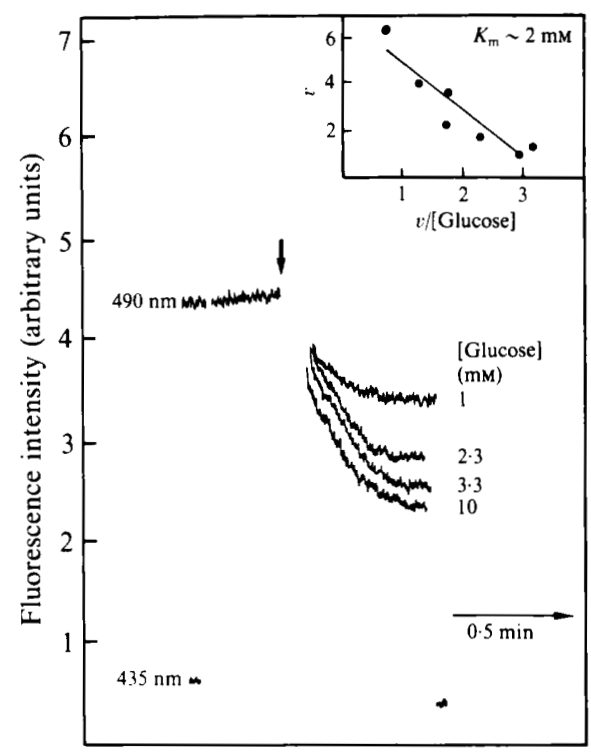

Fig. 4. Dependence of the rate of internal acidification on the concentration of added glucose. Cells were harvested, loaded with fluorescein and suspended in $50 \mathrm{~mm}-6$-aminohexanoate $/ \mathrm{HCl}$ buffer, $\mathrm{pH} 4 \cdot 5$. Fluorescence was recorded as in Fig. 3. The arrow indicates the addition of the concentrations of glucose indicated. Inset, Eadie-Hofstee plot of rates of decrease in fluorescence and the glucose concentrations shown, where $v$ is represented in relative fluorescence units $\mathrm{min}^{-1}$ and [glucose] in $\mathrm{mM}$.

similar to that of the high-affinity glucose carrier which has a $K_{\mathrm{m}}$ of $1.5 \mathrm{~mm}$ (Bisson \& Fraenkel, 1983 ) and higher than the $K_{\mathrm{m}}$ values of kinases, which are below $1 \mathrm{~mm}$ (Purich et al., 1973). This is not in conflict with data reported above where intracellular acidification induced by glucose was reported to be dependent on the phosphorylation of the sugar, because glucose transport is rate-limiting for sugar phosphorylation and hence for the acidification caused by this reaction. However, the $K_{\mathrm{m}}$ value determined for glucose for the glucose-induced internal acidification is 
very different from the $K_{\mathrm{m}}(25 \mathrm{~mm}$; Beullens et al., 1988) for glucose of the 'triggering reaction' that causes the increase of internal cAMP levels.

\section{DISCUSSION}

The results presented in this paper clearly show that the acidification induced in $S$. cerevisiae by the addition of glucose and other sugars, which are metabolized via the glycolytic pathway, is due to the phosphorylation of the sugar. This is supported by the lack of acidification observed when glucose was added to a mutant (D 308.3) deficient in all three sugar phosphorylating enzymes. The same lack of acidification was observed when sugars which are not efficiently phosphorylated were added. Moreover, since addition of glucose to the mutant AA28 (pgi1 1 ), which is unable to metabolize glucose 6-phosphate, caused an acidification similar to that observed in the wild-type, it can be concluded that the initial triggering reaction for glucoseinduced intracellular acidification is located after the transport process and before glucose 6phosphate isomerization. Any of the three glucose-phosphorylating enzymes in yeasts can mediate acidification upon glucose addition. The acidification could be due to the $\mathrm{H}^{+}$ion which is released during phosphorylation, since glucose 6-phosphate has a $\mathrm{p} K$ of 1.4 while the $\mathrm{p} K$ of dissociable groups of ATP is near 7.0. This excludes the possibility that $\mathrm{CO}_{2}$ or any other organic acids derived from glucose metabolism could be implicated in acidification since glucose, which is not metabolized beyond glucose 6-phosphate in the pgil $\Delta$ mutant, affects $\mathrm{pH}_{\mathrm{in}}$. In addition, the possibility of $\mathrm{H}^{+}$generation through the oxidation of glucose by the pentose phosphate shunt can be discounted since in strain AA28 fructose is as effective as glucose at inducing acidification. This strain requires small amounts of glucose to grow in a medium with fructose as carbon source (Aguilera, 1986), since glucans (Ballou, 1982) and inositol (Henry, 1982), as well as NADPH, are generated in yeasts from glucose 6-phosphate through direct oxidation (see Fraenkel, 1982). The glucose requirement of this strain indicates that fructose 6-phosphate cannot enter the pentose phosphate shunt.

The acidification caused by glucose was also observed in cells suspended in culture medium. In this case, the acidification was transient, as expected, due to the presence of $\mathrm{K}^{+}$in the culture medium (Valle et al., 1987). Interestingly, $\mathrm{pH}_{\text {in }}$ was $7 \cdot 1$ even though the $\mathrm{pH}$ of the medium was 3.1. This result conflicts with those of Borst-Pauwels (1981) and de la Peña et al. (1982), who showed that $\mathrm{pH}_{\mathrm{in}}$ was a function of $\mathrm{pH}_{\text {out }}$ in yeasts suspended in buffer with or without glucose. Our results indicate that when yeasts are suspended in culture medium, even if the sugar has been exhausted, they are more effective at maintaining their $\mathrm{pH}_{\mathrm{in}}$ than when suspended in buffer.

It is well-accepted that the internal acidification produced by $\mathrm{H}^{+}$conductors causes an increase in cAMP levels (Mazón et al., 1982; Thevelein et al., 1987a) and that the effect of uncouplers requires at least one functional $R A S$ gene, a fact indicating its physiological importance (Mbonyi et al., 1988). However, the question whether glucose-induced acidification mediates the increase in cAMP levels remains unanswered.

The results presented in this paper indicate that the internal acidification induced by glucose addition is a function of the concentration of glucose added but with a value for the apparent $K_{\mathrm{m}}$ of $2 \mathrm{mM}$. The different values for the glucose-triggered increase in cAMP levels and internal acidification might indicate that in addition to the internal acidification the signal that glucose produces is dependent on a different system with a lower affinity. It might well be the binding to a receptor [Beullens et al. (1988) support the hypothesis of the low-affinity transport system bound to a kinase], which, as demonstrated by these authors, is only expressed in glucosederepressed cells. In conclusion, our results indicate that although internal acidification might mediate the glucose-induced increase in cAMP, another mechanism with a lower affinity might also be involved. How the possible receptor interacts with adenylate cyclase and the GTPbinding RAS protein is not known at present.

We are indebted to Dr Andrés Aguilera, Department of Biochemistry, New York University Medical Center, for providing us with the strain AA28 and Dra Rosa Fernández for suggesting the determination of sugar 
phosphorylation. This work was supported by Grants from the Fondo de Investigaciones Sanitarias de la Seguridad Social, Ministerio de Sanidad y Consumo no. 88/1458 and Comisión Asesora de Investigación Cientifica y Técnica no. 0856-84. M.B. and L.A.P. are recipients of fellowships from F.I.S.

\section{REFERENCES}

Aguilera, A. (1986). Deletion of the phosphoglucose isomerase structural gene makes growth and sporulation glucose dependent in Saccharomyces cerevisiae. Molecular and General Genetics 204, 310-316.

BALLOU, C. E. (1982). Yeast cell wall and cell surfaces. In The Molecular Biology of the Yeast Saccharomyces. Metabolism and Gene Expression, pp. 335-360. Edited by N. J. Strathern, E. W. Jones \& J. R. Broach. Cold Spring Harbor, NY: Cold Spring Harbor Laboratory.

BARNARD, E. A. (1975). Hexokinases from yeasts. Methods in Enzymology 42C, 6-20.

Beullens, M., Mbonyi, K., GeerTs, L., Gladines, D., Detremerie, K., Jans, A. W. H. \& Thevelein, J. M. (1988). Studies on the mechanism of the glucoseinduced cAMP signal in glycolysis and glucose repression mutants of Saccharomyces cerevisiae. European Journal of Biochemistry 172, 227-231.

Bisson, L. F. \& Fraenkel, G. (1983). Involvement of kinases in glucose and fructose uptake by Saccharomyces cerevisiae. Proceedings of the National Academy of Sciences of the United States of America 80, 1730-1734.

Blatt, M. R. \& Slayman, C. L. (1987). Role of "active" postassium transport in the regulation of cytoplasmic $\mathrm{pH}$ by nonanimal cells. Proceedings of the National Academy of Sciences of the United States of America 84, 2737-2741.

BoRST-PAUWELS, G. W. F. H. (1981). Ion transport in yeast. Biochimica et biophysica acta 650, 88-127.

BusA, W. B. \& Nuccitelli, R. (1984). Metabolic regulation via intracellular pH. American Journal of Physiology 246, 409-438.

Caspani, G., Tortora, P., hanozet, G. M. \& GUERRITORE, A. (1985). Glucose-stimulated cAMP increase may be mediated by intracellular acidification in Saccharomyces cerevisiae. FEBS Letters 186, 75-79.

Duro, A. F. \& Serrano, R. (1981). Inhibition of succinate production during yeast fermentation by deenergization of the plasma membrane. Current Microbiology 6, 111-113.

ENTIAN, K. D. \& MECKE, D. (1981). Genetic evidence for a role of hexokinase isozyme PII in carbon catabolite repression in Saccharomyces cerevisiae. Journal of Biological Chemistry 257, 870-874.

Eraso, P., Mazon, M. J. \& Gancedo, J. M. (1987). Internal acidification and cAMP increase are not correlated in Saccharomyces cerevisiae. European Journal of Biochemistry 165, 671-674.

Fernández, R., Herrero, P. \& Moreno, F. (1985). Inhibition and inactivation of glucose-phosphorylating enzymes from Saccharomyces cerevisiae by Dxylose. Journal of General Microbiology 131, 2705-2709.

FraenKel, D. G. (1982). Carbohydrate metabolism. In The Molecular Biology of the Yeast Saccharomyces. Metabolism and Gene Expression, pp. 1-37. Edited by N. J. Strathern, E. W. Jones \& J. R. Broach. Cold
Spring Harbor, NY: Cold Spring Harbor Laboratory.

GaNCEDO, C. \& GANCEDO, J. M. (1985). Phosphorylation of 3-O-methyl-D-glucose and catabolite repression in yeast. European Journal of Biochemistry 148, 593-597.

Gancedo, J. M., Clifton, D. \& Fraenkel, D. G. (1977). Yeast hexokinase mutants. Journal of Biological Chemistry 252, 4443-4444.

Gofreau, A. \& Slayman, C. W. (1981). The protontranslocating ATPase of the fungal plasma membrane. Biochimica et biophysica acta 639, 197-223.

GrINSTEIN, S. \& RothsteIN, A. (1986). Mechanisms of regulation of the $\mathrm{Na}^{+} / \mathrm{H}^{+}$exchanger. Journal of Membrane Biology 90, 1-12.

Grinstein, S., GoetZ-Smith, J. D. \& COHEN, S. (1987). Cytoplasmic free $\mathrm{Ca}^{2+}$ and the intracellular $\mathrm{pH}$ of lymphocytes. In Cell Calcium and the Control of Membrane Transport (Society for General Physiology Series, vol. 42), pp. 215-228. Edited by L. J. Mandel \& D. C. Eaton. New York: Rockefeller University Press.

Henderson, L. M., Chappell, J. B. \& Jones, O. T. G. (1988). Internal $\mathrm{pH}$ changes associated with the activity of NADPH oxidase of human neutrophils. Biochemical Journal 251, 563-567.

HENRY, S. A. (1982). Membrane lipids of yeast: Biochemical and genetic studies. In The Molecular Biology of the Yeast Saccharomyces. Metabolism and Gene Expression, pp. 101-158. Edited by N. J. Strathern, E. W. Jones \& J. R. Broach. Cold Spring Harbor, NY: Cold Spring Harbor Laboratory.

DEN HOLLANDER, J. A., UgURBIL, K., BROWN, T. R. \& Shulman, R. G. (1981). Phosphorus-31 nuclear magnetic resonance studies of the effect of oxygen upon glycolysis in yeast. Biochemistry 20, 5871-5880.

IVES, H. E. \& DANIEL, T. O. (1987). Interrelationship between growth factor-induced $\mathrm{pH}$ changes and intracellular $\mathrm{Ca}^{2+}$. Proceedings of the National Academy of Sciences of the United States of America 84, 1950-1954.

Madshus, I. H. (1988). Regulation of internal pH in eucaryotic cells. Biochemical Journal 250, 1-8.

Mazón, M. J., Gancedo, J. M. \& GanCEDO, C. (1982). Phosphorylation and inactivation of yeast fructosebisphosphatase in vivo by glucose and proton ionophores. European Journal of Biochemistry 127, 605-608.

Mbonyi, K., Beullens, M., Detremerie, K., Geerts, L. \& Thevelein, J. M. (1988). Requirement of one functional RAS gene and inability of an oncogenic ras variant to mediate the glucose-induced cyclic AMP signal in the yeast Saccharomyces cerevisiae. Molecular and Cellular Biology 8, 3051-3057.

Nicolay, K., SchefFers, W. A., BRUinenberG, P. M. \& KAPTEIN, R. (1982). Phosphorus-31 nuclear magnetic resonance studies of intracellular $\mathrm{pH}$. Phosphate compartmentation and phosphate transport in yeast. Archives of Microbiology 133, 83-89. 
Ongjoco, R., SzKutnicka, K. \& Cirillo, V. P. (1987). Glucose transport in vesicles reconstituted from Saccharomyces cerevisiae membranes and liposomes. Journal of Bacteriology 169, 2926-2931.

de la Peña, P., Barros, F., Gascon, S., Ramos, S. \& LAzo, P. S. (1982). The electrochemical proton gradient of Saccharomyces. Role of potassium. European Journal of Biochemistry 123, 447-453.

van der PlaAt, J. B. \& van Soligen, P. (1974). Cyclic 3',5'adenosine monophosphate stimulates threalase degradation in baker's yeast. Biochemical and Biophysical Research Communications 56, 580-587.

Purich, D. L., Fromm, H. J. \& RudolPh, F. B. (1973). The hexokinases: kinetic, physical and regulatory properties. Advances in Enzymology 39, 249-326.

Purwin, C., Nicolay, K., Scheffers, A. \& Holzer, H. (1986). Mechanism of control of adenylate cyclase activity in yeast by fermentable sugars and carbonyl cyanide $m$-chlorophenylhydrazone. Journal of Biological Chemistry 261, 8744-8749.

Serrano, R. (1980). Effect of ATPase inhibitors on the proton pump of respiratory-deficient yeast. European Journal of Biochemistry 105, 419-424.

Serrano, R. (1984). Plasma membrane ATPase of fungi and plants as a novel type of proton pump. Current Topics on Cellular Regulation 23, 87-126.

Silverio, J. M., Valdes-Hevia, M. D. \& Gancedo, C. (1986). Toxicity of 3-O-methylglucose in yeast is due to its phosphorylation by glucokinase. FEBS Letters 194, 39-42.

SLAVIK, J. (1982). Intracellular $\mathrm{pH}$ of yeast measured with fluorescent probes. FEBS Letters 140, 22-26.
Sols, A., De la Fuente, G., Villar-Palasi, C. \& AsENSIO, C. (1958). Substrate specificity of and some other properties of baker's yeast hexokinase. Biochimica et biophysica acta 30, 92-101.

Thevelein, J. M., Beullens, M., Honshoven, F., Hoebeeck, G., Detremerie, K., Griewel, B., DEN Hollander, J. \& JANS, A. W. H. (1987a). Regulation of the cAMP level in the yeast Saccharomyces cerevisiae : intracellular $\mathrm{pH}$ and the effect of membrane depolarizing compounds. Journal of General Microbiology 133, 2191-2196.

Thevelein, J. M., Beullens, M., Honshoven, F., Hoebeeck, G., Detremerie, K., Griewel, B., DeN Hollander, J. \& Jans, A. W. H. (1987b). Regulation of the cAMP level in the yeast Saccharomyces cerevisiae: the glucose-induced CAMP signal is not mediated by a transient drop in the intracellular $\mathrm{pH}$. Journal of General Microbiology 133, 2197-2205.

Valle, E., Bergillos, L., Gascon, S., Parra, F. \& RAMOS, S. (1986). Trehalase activation in yeast is mediated by internal acidification. European Journal of Biochemistry 154, 247-251.

VALle, E., Bergillos, L. \& Ramos, S. (1987). External $\mathrm{K}^{+}$affects the internal acidification caused by the addition of glucose to yeast cells. Journal of General Microbiology 133, 535-538.

Wurst, M., Sigler, K. \& Knotkova, A. (1980). Gas chromatographic determination of extracellular metabolites produced by baker's yeast during glucose-induced acidification. Folia microbiologica 25, 306-310. 